\title{
ARTIGO
}

do] https://doi.org/10.22481/praxisedu.v16i40.6902

\section{A PRODUÇÃO DO CONHECIMENTO EM REVISTAS CIENTÍFICAS DO FEPAE-NNE}

\author{
THE PRODUCTION OF KNOWLEDGE IN SCIENTIFIC JOURNALS FROM THE FEPAE-NNE
}

\section{LA PRODUCCIÓN DE CONOCIMIENTO EN REVISTAS CIENTÍFICAS DEL FEPAE-NN}

\author{
Pedro Paulo Souza Rios \\ Universidade do Estado da Bahia - Brasil \\ André Ricardo Lucas Vieira \\ Instituto Federal do Sertão Pernambucano - Brasil \\ Willian Lima Santos \\ Universidade Federal de Sergipe - Brasil
}

Resumo: Este artigo teve por objetivo a realização de uma revisão sistematizada da literatura em periódicos integrantes do Fórum de Editores de Periódicos da Área de Educação - FEPAE/ANPED/Norte/Nordeste no período de 2005 a 2018. O processo metodológico que compôs os diferentes resultados encontrados, a partir dos textos mais citados dessas revistas, foi pautado na revisão sistematizada que é uma modalidade de pesquisa, que segue protocolos específicos e busca dar logicidade a um grande corpus documental. Após aplicar os critérios de exclusão/inclusão verificou-se que os estudos com maior notoriedade se concentram nas áreas de formação e competência docente e políticas públicas educacionais. Foi possível perceber ainda o quanto as pesquisas em educação têm se debruçado no sentido de compreender de que maneira as questões contemporâneas, influenciam e são influenciadas pelas práticas pedagógicas. Por fim, asseguramos que tais pesquisas ratificam o nordeste e o norte do Brasil enquanto territórios produtores e difusores do conhecimento em educação.

Palavras chave: Produção Cientifica; Revisão de Literatura; Pesquisa em Educação.

\begin{abstract}
This article aimed to carry out a systematic review of the literature in journals that are part of the Forum of Editors of Journals in the Education Area - FEPAE / ANPED / North / Northeast from 2005 to 2018. The methodological process that composed the different results found, based on the most cited texts in these journals, was guided by the systematic review, which is a research modality, which follows specific protocols and seeks to give logic to a large documentary corpus. After applying the exclusion / inclusion criteria, it was found that the most notorious studies are concentrated in the areas of teacher training and competence and public educational policies. It was also possible to perceive how much research in education has focused on understanding how contemporary issues influence and are influenced by pedagogical practices. Finally, we ensure that such research ratifies the northeast and north of Brazil as territories that produce and disseminate knowledge in education.
\end{abstract}

Keywords: Scientific production; Literature review; Education Research. 
Resumen: Este artículo tenía como objetivo llevar a cabo una revisión sistemática de la literatura en revistas que forman parte del Foro de Editores de Revistas en el Área de Educación - FEPAE / ANPED / Norte / Nordeste de 2005 a 2018. El proceso metodológico que compuso los diferentes resultados encontrados, basado en los textos más citados en estas revistas, se guió por la revisión sistemática, que es una modalidad de investigación, que sigue protocolos específicos y busca dar lógica a un gran corpus documental. Después de aplicar los criterios de exclusión / inclusión, se descubrió que los estudios más notorios se concentran en las áreas de capacitación y competencia docente y políticas educativas públicas. También fue posible percibir cuánta investigación en educación se ha centrado en comprender cómo los problemas contemporáneos influyen y son influenciados por las prácticas pedagógicas. Finalmente, nos aseguramos de que dicha investigación ratifique el noreste y el norte de Brasil como productores y diseminadores de conocimiento en educación.

Palabras clave: Producción Científica; Revisión de Literatura; Investigación Educativa.

\section{Introdução: pesquisa em educação}

A revisão de literatura se configura enquanto instrumento científico indispensável no trabalho acadêmico, já que é por meio dessa ferramenta que é assegurado a inserção da produção científica na grande área de pesquisa da qual faz parte. Assim, podemos dizer que a tal atividade é parte vital do processo de investigação e difusão do conhecimento.

Comumente o processo de produção e disseminação do conhecimento no Brasil sempre esteve associado a expansão da pós-graduação. É através dos cursos de pós-graduação e sistematização de revistas e outros mecanismos que se tem buscado consolidar a base científica e formar recursos humanos qualificados para solucionar problemas, além de ampliar os saberes produzidos por meio de pesquisa em âmbito regional e nacional (ECHER, 2001).

Assim, o presente artigo analisa as dez (10) produções científicas mais citadas em estudos acadêmicos publicadas nas Revistas Tempos e Espaços em Educação, do Programa de PósGraduação em Educação - PPGED, da Universidade Federal de Sergipe - UFS; Práxis Educacional, Programa de Pós-Graduação em Educação - PPGEd, da Universidade Estadual do Sudoeste da Bahia - UESB; Exitus, Programa de Pós-graduação em Educação da Universidade Federal do Oeste do Pará - UFOPA e; Educação e Formação, do Programa de Pós-Graduação em Educação - PPGE, da Universidade Estadual do Ceará - UECE. Entendemos, dessa maneira, que a educação se apresenta num campo de produção que agrega distintas áreas do conhecimento, considerando os conceitos basilares para estabelecer princípios que possam auxiliar na organização do processo ensino-aprendizagem.

Na primeira parte são apresentados os artigos mais citados nas Revistas, ao tempo em que sucitamos a importância da pesquisa a partir das produções analisadas. Num segundo momento 
fizemos a categorização dos temas abordados buscando compreender quais são as categorias mais recorrentes nos referidos estudos.

\section{A trilha da Revisão Sistemática}

Fundamentada em evidências, cujos resultados de pesquisas são coletados, categorizados, avaliados e sintetizados, a revisão sistemática é um tipo de investigação científica. Salienta-se que a partir da última década, esta abordagem científica vem sendo inserida com maior frequência nas pesquisas de Ciências Humanas, com o objetivo de se evidenciar aquilo que se tem produzido sobre uma questão particular.

A revisão sistemática diferencia-se da tradicional, já que transcende prováveis vieses em todas as etapas, percorrendo uma metodologia rígida de busca e seleção de pesquisas, analisando a legitimidade do que foi encontrado e coletando, sintetizando e interpretando os dados provenientes das investigações.

Já no que tange a área da educação, a revisão sistemática de literatura, abarca importantes contribuições, dentre elas, "a concentração de resultados de vários outros estudos num mesmo trabalho, aumentando a confiabilidade e revelando o status de um problema de pesquisa" (DIAS; AMORIM, 2015, p. 196). Nesta perspectiva, e reconhecendo o potencial desse tipo de investigação científica, optamos por fazer uso do planejamento desenvolvido por Cooper (2010), devidamente utilizado no campo da ciência política (FIGUEIREDO FILHO et. al., 2014).

Tal planejamento, organiza-se em sete etapas: 1) identificação e formulação do problema de pesquisa; 2) coleção de literatura (nesta oportunidade, o levantamento dos artigos mais citados nos periódicos filiados ao FEPAI-NN); 3) coleta de informações de cada estudo; 4) avaliar a qualidade dos estudos; 5) análise e síntese dos resultados dos estudos; 6) interpretação dos dados coletados e 7) apresentação dos resultados.

Destarte, com vistas a delimitação das produções a serem compiladas, é basilar que definamos procedimentos de exclusão/inclusão. Neste sentido, no que se refere a esses procedimentos de exclusão/inclusão, optamos por: a) periódicos filiados ao FEPAE-NN; b) indexação na Web of Science; c) os dez artigos mais citados em cada um desses periódicos e d) artigos sem restrição de idioma.

Após termos procedido a análise inicial junto aos periódicos filiados ao FEPAE-NN encontramos três periódicos indexados na base Web of Science, sendo eles: Revista Práxis Educacional, Revista Tempos e Espaços em Educação e a Revista Educação \& Formação, ambas vinculadas a instituições públicas na região Nordeste. Em virtude de termos encontrado, neste 
caso, apenas periódicos da região nordeste, e reconhecendo a necessidade de inserir resultados da região Norte, optamos por incluir a Revista Exitus em detrimento de outros dois importantes indexadores que o periódico possui.

É importante frisar que a seleção dos textos se deu no dia 17 de abril de 2020 devido ao número de citações que pode variar após essa data, alterando assim a ordem dos textos mais ou menos citados destes periódicos.

No que se refere aos dez artigos mais citados de cada uma dessas revistas, convém destacarmos que no periódico Tempos e Espaços em Educação o décimo artigo mais citado possuía a mesma quantidade de citações do décimo primeiro e décimo segundo e no periódico Práxis Educacional o décimo artigo mais citado também possuía a mesma quantidade de citações do décimo primeiro. Neste sentido adotamos por critério que todos os textos com o mesmo número de citações do décimo artigo de cada periódico seria também incluído na relação dos textos a serem analisados. Desta forma o total de artigos, aplicados todos os critérios aqui descritos, foi de 43 artigos.

\section{Artigos mais citados: a expansão da pesquisa em educação}

Os artigos mais citados foram publicados entre os anos de 2005 e 2018. A Práxis Educacional tem o maior número de citações, sendo 884, obtendo índices h 14 e i10 24. Em seguida as Revistas Tempos e Espaços em Educação e Educação e Formação com 599 citações, sendo que a primeira tem o índice h 11 e índice 110 14, enquanto que a segunda com o mesmo número de citações tem o índice h 4 e índice i10 0. A Revista Exitus teve 399 citações com índice h 8 e índice $i 107$.

Destacamos que o índice h representa as h produções com no mínimo h citações nos últimos 5 anos, enquanto o índice i10 representa o número de publicações com, no mínimo, 10 citações nos mesmos 5 anos.

QUADRO 01- Revistas por número de citação

\begin{tabular}{|l|c|c|c|}
\hline \multicolumn{1}{|c|}{ TITULO } & $\begin{array}{c}\mathbf{N}^{\mathbf{0}} \mathbf{D E} \\
\text { CITAÇÃO }\end{array}$ & AUTOR(ES) & PERIÓDICO \\
\hline $\begin{array}{l}\text { O livro didático e suas implicações na } \\
\text { prática do professor nas escolas públicas } \\
\text { de Guajará-mirim. }\end{array}$ & 43 & $\begin{array}{c}\text { APARECIDA Nechi Verceze, } \\
\text { Rosa Maria; MOREIRA } \\
\text { Silvino, Eliziane França (2010) }\end{array}$ & Práxis Educacional \\
\hline $\begin{array}{l}\text { Educação de Jovens e Adultos: uma } \\
\text { história de complexidade e tensões }\end{array}$ & 42 & $\begin{array}{c}\text { SAMPAIO, Marisa Narcizo } \\
(2009)\end{array}$ & Práxis Educacional \\
\hline $\begin{array}{l}\text { Formação de educadores de jovens e } \\
\text { adultos: realidade, desafios e perspectivas } \\
\text { atuais }\end{array}$ & 40 & $\begin{array}{c}\text { DE MELO MOURA, Tania } \\
\text { Maria (2010) }\end{array}$ & Práxis Educacional \\
\hline Educação inclusiva na educação infantil & 38 & $\begin{array}{c}\text { CARBONE Carneiro, Relma } \\
\text { Urel (2012) }\end{array}$ & Práxis Educacional \\
\hline
\end{tabular}




\begin{tabular}{|c|c|c|c|}
\hline $\begin{array}{l}\text { A aprendizagem ubíqua na educação } \\
\text { aberta }\end{array}$ & 33 & SANTAELLA, Lucia (2014) & $\begin{array}{l}\text { Revista Tempos e } \\
\text { Espaços em } \\
\text { Educação }\end{array}$ \\
\hline $\begin{array}{l}\text { A proposta de inclusão escolar no } \\
\text { contexto nacional de implementação das } \\
\text { políticas educacionais }\end{array}$ & 25 & $\begin{array}{c}\text { MATOS, Selma Norberto; } \\
\text { MENDES, Enicéia Gonçalves } \\
\text { (2014) }\end{array}$ & Práxis Educacional \\
\hline $\begin{array}{l}\text { La construcción de una identidad } \\
\text { docente, ¿un desafío para la política } \\
\text { educativa? }\end{array}$ & 23 & $\begin{array}{l}\text { RODRIGUEZ, Linda Grace } \\
\text { Matus (2013) }\end{array}$ & Revista Exitus \\
\hline $\begin{array}{l}\text { A aprendizagem da docência no início da } \\
\text { carreira: Qual política? Quais problemas? }\end{array}$ & 20 & $\begin{array}{l}\text { MARIANO, André Luiz Sena } \\
\text { (2012) }\end{array}$ & Revista Exitus \\
\hline $\begin{array}{l}\text { História da Disciplina Português na } \\
\text { Escola Secundária Brasileira }\end{array}$ & 20 & $\begin{array}{l}\text { RAZZINI, Marcia de Paula } \\
\text { Gregório (2010) }\end{array}$ & $\begin{array}{l}\text { Revista Tempos e } \\
\text { Espaços em } \\
\text { Educação }\end{array}$ \\
\hline $\begin{array}{l}\text { Competência: uma noção plástica, } \\
\text { polissêmica e polimorfa }\end{array}$ & 20 & $\begin{array}{l}\text { LOPES PEREZ, Maria Isabel } \\
\text { (2005) }\end{array}$ & Práxis Educacional \\
\hline $\begin{array}{l}\text { Competencia de reflexión en la formación } \\
\text { inicial de profesores de matemática en } \\
\text { Chile }\end{array}$ & 19 & $\begin{array}{c}\text { SECKEL, María José; FONT, } \\
\text { Vicenç (2015) }\end{array}$ & Práxis Educacional \\
\hline $\begin{array}{l}\text { Avaliação da aprendizagem no ensino } \\
\text { superior: aspectos históricos }\end{array}$ & 19 & $\begin{array}{l}\text { SOUZA, Ana Maria de Lima } \\
\text { (2012) }\end{array}$ & Revista Exitus \\
\hline $\begin{array}{l}\text { O ensino de nível superior no Brasil e as } \\
\text { competências docentes: um olhar } \\
\text { reflexivo sobre esta prática }\end{array}$ & 19 & $\begin{array}{l}\text { CAVALCANTI Valente, Geilsa } \\
\text { Soraia; VIANA, Ligia de } \\
\text { Oliveira (2010) } \\
\end{array}$ & Práxis Educacional \\
\hline $\begin{array}{l}\text { Didática: uma esperança para as } \\
\text { dificuldades pedagógicas do ensino } \\
\text { superior? }\end{array}$ & 18 & $\begin{array}{c}\text { SANTORO Franco, Maria } \\
\text { Amélia (2013) }\end{array}$ & Práxis Educacional \\
\hline $\begin{array}{l}\text { Competências profissionais na formação } \\
\text { inicial de professores de matemática }\end{array}$ & 17 & $\begin{array}{c}\text { FONT, Vicença; BREDA, } \\
\text { Adriana (2015) }\end{array}$ & Práxis Educacional \\
\hline $\begin{array}{l}\text { O surgimento da educação infantil na } \\
\text { história das políticas públicas para a } \\
\text { criança no Brasil }\end{array}$ & 17 & $\begin{array}{l}\text { MORAES DA SILVA, Carmem } \\
\text { Virgínia; FRANCISCHINI, } \\
\text { Rosângela (2012) } \\
\end{array}$ & Práxis Educacional \\
\hline $\begin{array}{l}\text { Práxis pedagógica e professores } \\
\text { intelectuais: refletindo as tensões e } \\
\text { concepções da formação/prática docente }\end{array}$ & 17 & $\begin{array}{l}\text { S. FREITAS, Maria Auxiliadora } \\
\qquad(2010)\end{array}$ & Práxis Educacional \\
\hline $\begin{array}{l}\text { O uso de dispositivos móveis no } \\
\text { contexto educativo: análise de teses e } \\
\text { dissertações nacionais }\end{array}$ & 16 & $\begin{array}{l}\text { ALMEIDA, Rosiney Rocha; } \\
\text { ARAUJO Jr, Carlos Araújo } \\
\text { Fernando de. (2013) }\end{array}$ & $\begin{array}{l}\text { Revista Tempos e } \\
\text { Espaços em } \\
\text { Educação }\end{array}$ \\
\hline $\begin{array}{l}\text { Civilizar a infância na Renascença: } \\
\text { estratégia de distinção de classe }\end{array}$ & 16 & BOTO, Carlota (2009) & $\begin{array}{l}\text { Revista Tempos e } \\
\text { Espaços em } \\
\text { Educação } \\
\end{array}$ \\
\hline $\begin{array}{l}\text { Como as escolas educam corpos nas } \\
\text { práticas pedagógicas? }\end{array}$ & 16 & DIAS, Alfrancio Ferreira (2014) & $\begin{array}{l}\text { Revista Tempos e } \\
\text { Espaços em } \\
\text { Educação } \\
\end{array}$ \\
\hline $\begin{array}{l}\text { Políticas públicas de formação de } \\
\text { professores: o Pibid em foco }\end{array}$ & 15 & $\begin{array}{l}\text { TANCREDI, Regina Maria } \\
\text { Simões Puccinelli (2013) }\end{array}$ & Revista Exitus \\
\hline $\begin{array}{l}\text { Ambiente, Educação } \\
\text { Interculturalidade }\end{array}$ & 15 & $\begin{array}{l}\text { RAMOS, Maria da Conceição } \\
\text { Pereira (2012) }\end{array}$ & $\begin{array}{l}\text { Revista Tempos e } \\
\text { Espaços em } \\
\text { Educação }\end{array}$ \\
\hline $\begin{array}{l}\text { A crítica feminista à ciência e } \\
\text { contribuição à pesquisa nas ciências } \\
\text { humanas }\end{array}$ & 14 & $\begin{array}{l}\text { CRUZ, Maria Helena Santana } \\
\text { (2014) }\end{array}$ & $\begin{array}{l}\text { Revista Tempos e } \\
\text { Espaços em } \\
\text { Educação }\end{array}$ \\
\hline $\begin{array}{l}\text { A Educação de Jovens e Adultos no } \\
\text { sistema prisional brasileiro: o que } \\
\text { dizem os planos estaduais de educação } \\
\text { em prisões? }\end{array}$ & 13 & PEREIRA, Antônio (2018) & $\begin{array}{l}\text { Revista Tempos e } \\
\text { Espaços em } \\
\text { Educação }\end{array}$ \\
\hline $\begin{array}{l}\text { Desempenho escolar e vulnerabilidade } \\
\text { social. }\end{array}$ & 13 & $\begin{array}{l}\text { CALEJON, Laura Marisa } \\
\text { Carnielo (2011) }\end{array}$ & Revista Exitus \\
\hline
\end{tabular}




\begin{tabular}{|c|c|c|c|}
\hline $\begin{array}{l}\text { Pedagogia da corporeidade: o decifrar } \\
\text { e o subjetivar na educação }\end{array}$ & 12 & $\begin{array}{l}\text { GOMES-DA-SILVA, Pierre } \\
\text { Normando (2014) }\end{array}$ & $\begin{array}{l}\text { Revista Tempos e } \\
\text { Espaços em } \\
\text { Educação }\end{array}$ \\
\hline $\begin{array}{l}\text { As políticas educacionais da Nova } \\
\text { República: do governo Collor ao de Lula }\end{array}$ & 12 & $\begin{array}{l}\text { JACOMELI, Mara Regina } \\
\text { Martins (2011) }\end{array}$ & Revista Exitus \\
\hline $\begin{array}{l}\text { Inovação pedagógica e ortodoxia } \\
\text { curricular }\end{array}$ & 11 & FINO, Carlos Nogueira (2016) & $\begin{array}{l}\text { Revista Tempos e } \\
\text { Espaços em } \\
\text { Educação } \\
\end{array}$ \\
\hline $\begin{array}{l}\text { Non-affirmative curriculum theory in } \\
\text { a cosmopolitan era? }\end{array}$ & 11 & ULJENS, Michael (2016) & $\begin{array}{l}\text { Revista Tempos e } \\
\text { Espaços em } \\
\text { Educação } \\
\end{array}$ \\
\hline $\begin{array}{l}\text { O que um mentor precisa saber? Ou: } \\
\text { sobre a necessidade de um mentor } \\
\text { construir uma visão multifocal. }\end{array}$ & 10 & $\begin{array}{l}\text { TANCREDI, Regina Maria } \\
\text { Simões Puccinelli; REALI, } \\
\text { Aline Maria Medeiros } \\
\text { Rodrigues (2011) }\end{array}$ & Revista Exitus \\
\hline $\begin{array}{l}\text { Formação Docente: } \mathrm{O} \text { profissional da } \\
\text { sociedade contemporânea }\end{array}$ & 9 & $\begin{array}{c}\text { CORRADINI, Suely } \\
\text { Nercessian; MIZUKAMI, Maria } \\
\text { da Graça Nicoletti (2011) }\end{array}$ & Revista Exitus \\
\hline $\begin{array}{l}\text { Os conceitos de concepção, } \\
\text { percepção, representação e crença no } \\
\text { campo educacional: similaridades, } \\
\text { diferenças e implicações para a } \\
\text { pesquisa }\end{array}$ & 8 & $\begin{array}{l}\text { MATOS, Daniel Abud Seabra; } \\
\text { JARDILINO, José Rubens } \\
\text { Lima (2016) }\end{array}$ & $\begin{array}{l}\text { Educação \& } \\
\text { Formação }\end{array}$ \\
\hline $\begin{array}{lll}\text { Políticas públicas e formação } & \text { de } \\
\text { professores sob a perspectiva } & \text { da } \\
\text { racionalidade comunicativa: } & \text { da } \\
\text { ingerência tecnocrata à construção } & \text { da } \\
\text { autonomia profissional } & & \\
\end{array}$ & 8 & BEGO, Amadeu Moura (2016) & $\begin{array}{l}\text { Educação \& } \\
\text { Formação }\end{array}$ \\
\hline $\begin{array}{l}\text { A formação de modelos mentais na sala } \\
\text { de aula }\end{array}$ & 8 & $\begin{array}{c}\text { SOUZA, Edilson Sérgio } \\
\text { Ramalho de (2013) } \\
\end{array}$ & Revista Exitus \\
\hline $\begin{array}{l}\text { As avaliações estandartizadas e o papel } \\
\text { do Exame Nacional do Ensino Médio } \\
\text { (ENEM) na etapa final da Educação } \\
\text { Básica }\end{array}$ & 8 & $\begin{array}{l}\text { CARNEIRO, Verônica Lima } \\
\text { (2012) }\end{array}$ & Revista Exitus \\
\hline $\begin{array}{l}\text { The history of initial teacher } \\
\text { education in Canada: Québec and } \\
\text { Ontario }\end{array}$ & 6 & $\begin{array}{l}\text { SMYTH, Elizabeth; HAMEL, } \\
\text { Thérère (2016) }\end{array}$ & $\begin{array}{l}\text { Educação \& } \\
\text { Formação }\end{array}$ \\
\hline $\begin{array}{l}\text { Valores, educação infantil e } \\
\text { desenvolvimento moral: concepções } \\
\text { dos professores }\end{array}$ & 5 & $\begin{array}{l}\text { LIMA, Juliana dos Santos; } \\
\text { SANTOS, Gilberto Lima dos } \\
\text { (2018) }\end{array}$ & $\begin{array}{l}\text { Educação \& } \\
\text { Formação }\end{array}$ \\
\hline $\begin{array}{l}\text { A influência da formação continuada } \\
\text { na prática docente }\end{array}$ & 4 & MORORÓ, Leila Pio (2017) & $\begin{array}{l}\text { Educação \& } \\
\text { Formação }\end{array}$ \\
\hline $\begin{array}{l}\text { The (im) possibility of the intellectual } \\
\text { worker inside the neoliberal university }\end{array}$ & 4 & $\begin{array}{c}\text { BANFIELD, Grant; } \\
\text { HADUNTZ, Helen; } \\
\text { MAISURIA, Alpesh (2016) }\end{array}$ & $\begin{array}{l}\text { Educação \& } \\
\text { Formação }\end{array}$ \\
\hline $\begin{array}{l}\text { A abordagem da ação crítica e a } \\
\text { epistemologia da práxis pedagógica }\end{array}$ & 3 & GENÚ, Marta Soares (2018) & $\begin{array}{l}\text { Educação \& } \\
\text { Formação }\end{array}$ \\
\hline $\begin{array}{l}\text { A culpabilidade pelo fracasso escolar e } \\
\text { a interface com os "problemas de } \\
\text { aprendizagem" em discurso }\end{array}$ & 3 & $\begin{array}{c}\text { PEREIRA, Anderson Carvalho; } \\
\text { RIBEIRO, Carme Sandra de } \\
\text { Jesus (2017) } \\
\end{array}$ & $\begin{array}{l}\text { Educação \& } \\
\text { Formação }\end{array}$ \\
\hline $\begin{array}{l}\text { Políticas de redução da desigualdade } \\
\text { sociocultural }\end{array}$ & 3 & $\begin{array}{c}\text { LARA, Angela Mara Barros } \\
\text { (2016) } \\
\end{array}$ & $\begin{array}{l}\text { Educação \& } \\
\text { Formação }\end{array}$ \\
\hline $\begin{array}{l}\text { Espaço poético como tradução } \\
\text { didática: Bachelard e a imagem da casa }\end{array}$ & 3 & $\begin{array}{c}\text { DINARTE, Luiz Daniel } \\
\text { Rodrigues; CORAZZA, Sandra } \\
\text { Mara (2016) } \\
\end{array}$ & $\begin{array}{l}\text { Educação \& } \\
\text { Formação }\end{array}$ \\
\hline
\end{tabular}

FONTE: Elaboração dos autores (2020). 
De acordo com Gatti (2012) até a década de 1990 a pesquisa em educação no Brasil era escassa e centrada nas regiões sul e sudeste e, se debruçavam basicamente sobre questões inerentes a psicopedagogia, o desenvolvimento psicológico e a aprendizagem de crianças e adolescentes.

Apenas com a expansão das universidades e dos programas de Pós-Graduação na década de 1990 fica perceptível a expansão da produção científica na área de educação e associada a esse fenômeno é notório também a diversificação nas temáticas abordadas, perpassando desde as questões mais objetivas até as mais subjetivas do fazer pedagógico.

Uma breve análise do Quadro 01, nos ajuda a compreender melhor o que estamos suscitando. Consideramos que uma primeira questão a ser pontuada é o fato de que os estudos analisados nesses artigos foram publicados em revistas das regiões Nordeste e Norte do Brasil.

Um segundo elemento a ser pontuado é a variedades de assuntos próprios das questões da área da educação, abordados nas quatro revistas. Temas que perpassam desde os aspectos diretamente ligados a história da educação (SAMPAIO, 2009); (BOTO, 2009); (RAZZINI, 2010); (MORAES; FRANCISCHINI, 2012); (SMYTH, HAMEL, 2016); (BANFIELD; HADUNTZ; MAISURIA, 2016), formação docente e práticas pedagógicas (MOURA, 2010; CAVALCANTI; VIANA, 2010; TANCREDI; REALI, 2011; MARIANO, 2012; FRANCO, 2013; DINARTE; CORAZZA, 2016; GENÚ, 2018), políticas educacionais, avaliação e currículo (JACOMELI, 2011; CARBONE, 2012; TANCREDI, 2013; MATOS; MENDES, 2014; LARA, 2016; FINO, 2016; PEREIRA, 2018), as questões no campo da aprendizagem (CALEJON, 2011; SOUZA, 2013; PEREIRA; RIBEIRO, 2017), até as questões mais contemporâneas como equidade de gênero, tecnologia e educação ambiental ((RAMOS, 2012; ALMEIDA; ARAUJO JÚNIOR 2013; DIAS, 2014; CRUZ, 2014; SANTAELLA, 2014).

A partir do Quadro 1 é possível inferir que a pesquisa no campo da Educação tem tido um crescimento considerável de pesquisas em torno de distintos temas que discorrem acerca dos processos educativos a partir de diferentes ângulos, perspectivas e análises. No capítulo seguinte faremos uma análise mais detalhada e categorizada das temáticas elucidadas acima.

\section{Análise e discussão: principais categorias suscitadas}

Considerando o objetivo proposto nesse estudo, após o levantamento das publicações passamos para a etapa seguinte, que foi a de classificar por categorizar os 43 estudos mais citados. Nessa etapa, os artigos foram lidos, selecionados criteriosamente e agrupados em nove categorias, é pertinente ressaltar que como critério para estabelecer as categorias utilizamos os resumos e as palavras-chave, ficando assim definido: 1) Formação e Competência Docente; 2) História da 
Educação; 3) Políticas Públicas Educacionais; 4) Currículo e Avaliação Educacional; 5) Prática e Concepção Docente; 6) Tecnologia Digital e Educação; 7) Educação Ambiental; 8) Gênero e Educação e; 9) Aprendizagem escolar, conforme descrito no Quadro 02.

QUADRO 02 - Categorias dos assuntos mais citados

\begin{tabular}{|c|c|c|c|}
\hline CATEGORIAS & TÍTULO & AUTOR & PERIÓDICO \\
\hline \multirow{9}{*}{$\begin{array}{l}\text { Formação e } \\
\text { Competência } \\
\text { Docente }\end{array}$} & $\begin{array}{l}\text { Formação de educadores de jovens e } \\
\text { adultos: realidade, desafios e } \\
\text { perspectivas atuais }\end{array}$ & $\begin{array}{l}\text { MOURA, Tania de Melo Maria } \\
(2010)\end{array}$ & Práxis Educacional \\
\hline & $\begin{array}{l}\text { Formação Docente: O profissional } \\
\text { da sociedade contemporânea }\end{array}$ & $\begin{array}{l}\text { CORRADINI, Suely } \\
\text { Nercessian; MIZUKAMI, Maria } \\
\text { da Graça Nicoletti (2011) }\end{array}$ & Revista Exitus \\
\hline & $\begin{array}{l}\text { A influência da formação } \\
\text { continuada na prática docente }\end{array}$ & MORORÓ, Leila Pio (2017) & $\begin{array}{c}\text { Educação \& } \\
\text { Formação }\end{array}$ \\
\hline & $\begin{array}{l}\text { A aprendizagem da docência no } \\
\text { início da carreira: Qual política? } \\
\text { Quais problemas? }\end{array}$ & $\begin{array}{l}\text { MARIANO, André Luiz Sena } \\
\text { (2012) }\end{array}$ & Revista Exitus \\
\hline & $\begin{array}{l}\text { O que um mentor precisa saber? Ou: } \\
\text { sobre a necessidade de um mentor } \\
\text { construir uma visão multifocal. }\end{array}$ & $\begin{array}{c}\text { TANCREDI, Regina Maria } \\
\text { Simões Puccinelli; REALI, } \\
\text { Aline Maria Medeiros } \\
\text { Rodrigues (2011) } \\
\end{array}$ & Revista Exitus \\
\hline & $\begin{array}{l}\text { La construcción de una identidad } \\
\text { docente, ¿un desafío para la política } \\
\text { educativa? }\end{array}$ & $\begin{array}{l}\text { RODRIGUEZ, Linda Grace } \\
\text { Matus (2013) }\end{array}$ & Revista Exitus \\
\hline & $\begin{array}{l}\text { Competência: uma noção plástica, } \\
\text { polissêmica e polimorfa }\end{array}$ & $\begin{array}{l}\text { PEREZ, Maria Isabel Lopes } \\
(2005)\end{array}$ & Práxis Educacional \\
\hline & $\begin{array}{l}\text { Competencia de reflexión en la } \\
\text { formación inicial de profesores de } \\
\text { matemática en Chile }\end{array}$ & $\begin{array}{l}\text { SECKEL, María José; FONT, } \\
\text { Vicenç (2015) }\end{array}$ & Práxis Educacional \\
\hline & $\begin{array}{l}\text { Competências profissionais na } \\
\text { formação inicial de professores de } \\
\text { matemática }\end{array}$ & $\begin{array}{l}\text { FONT, Vicenç; BREDA, } \\
\text { Adriana (2015) }\end{array}$ & Práxis Educacional \\
\hline \multirow{9}{*}{$\begin{array}{l}\text { História da } \\
\text { Educação }\end{array}$} & $\begin{array}{l}\text { História da Disciplina Português na } \\
\text { Escola Secundária Brasileira }\end{array}$ & $\begin{array}{l}\text { RAZZINI, Marcia de Paula } \\
\text { Gregório (2010) }\end{array}$ & $\begin{array}{l}\text { Revista Tempos e } \\
\text { Espaços em } \\
\text { Educação } \\
\end{array}$ \\
\hline & $\begin{array}{l}\text { Civilizar a infância na Renascença: } \\
\text { estratégia de distinção de classe }\end{array}$ & BOTO, Carlota (2009) & $\begin{array}{l}\text { Revista Tempos e } \\
\text { Espaços em } \\
\text { Educação }\end{array}$ \\
\hline & $\begin{array}{l}\text { Educação de Jovens e Adultos: uma } \\
\text { história de complexidade e tensões }\end{array}$ & $\begin{array}{c}\text { SAMPAIO, Marisa Narcizo } \\
(2009)\end{array}$ & Práxis Educacional \\
\hline & $\begin{array}{l}\text { The history of initial teacher } \\
\text { education in Canada: Québec and } \\
\text { Ontario }\end{array}$ & $\begin{array}{l}\text { SMYTH, Elizabeth; HAMEL, } \\
\text { Thérère (2016) }\end{array}$ & $\begin{array}{l}\text { Educação \& } \\
\text { Formação }\end{array}$ \\
\hline & $\begin{array}{l}\text { The (im) possibility of the } \\
\text { intellectual worker inside the } \\
\text { neoliberal university }\end{array}$ & $\begin{array}{c}\text { BANFIELD, Grant; } \\
\text { HADUNTZ, Helen; } \\
\text { MAISURIA, Alpesh (2016) }\end{array}$ & $\begin{array}{l}\text { Educação \& } \\
\text { Formação }\end{array}$ \\
\hline & $\begin{array}{l}\text { O surgimento da educação infantil } \\
\text { na história das políticas públicas } \\
\text { para a criança no Brasil }\end{array}$ & $\begin{array}{l}\text { MORAES DA SILVA, Carmem } \\
\text { Virgínia; FRANCISCHINI, } \\
\text { Rosângela (2012) }\end{array}$ & Práxis Educacional \\
\hline & $\begin{array}{l}\text { Políticas de redução da desigualdade } \\
\text { sociocultural }\end{array}$ & $\begin{array}{l}\text { LARA, Angela Mara Barros } \\
(2016)\end{array}$ & $\begin{array}{c}\text { Educação \& } \\
\text { Formação }\end{array}$ \\
\hline & $\begin{array}{l}\text { Educação inclusiva na educação } \\
\text { infantil }\end{array}$ & $\begin{array}{c}\text { CARBONE CARNEIRO, } \\
\text { Relma Urel (2012) } \\
\end{array}$ & Práxis Educacional \\
\hline & $\begin{array}{l}\text { A proposta de inclusão escolar no } \\
\text { contexto nacional de implementação } \\
\text { das políticas educacionais }\end{array}$ & $\begin{array}{l}\text { MATOS, Selma Norberto; } \\
\text { MENDES, Enicéia Gonçalves } \\
\text { (2014) }\end{array}$ & Práxis Educacional \\
\hline
\end{tabular}




\begin{tabular}{|c|c|c|c|}
\hline \multirow{4}{*}{$\begin{array}{c}\text { Políticas } \\
\text { Públicas } \\
\text { Educacionais }\end{array}$} & $\begin{array}{l}\text { Políticas públicas de formação de } \\
\text { professores: o Pibid em foco }\end{array}$ & $\begin{array}{l}\text { TANCREDI, Regina Maria } \\
\text { Simões Puccinelli (2013) }\end{array}$ & Revista Exitus \\
\hline & $\begin{array}{l}\text { A educação de jovens e adultos no } \\
\text { sistema prisional brasileiro: o que } \\
\text { dizem os planos estaduais de } \\
\text { educação em prisões? }\end{array}$ & PEREIRA, Antônio (2018) & $\begin{array}{l}\text { Revista Tempos e } \\
\text { Espaços em } \\
\text { Educação }\end{array}$ \\
\hline & $\begin{array}{l}\text { As políticas educacionais da Nova } \\
\text { República: do governo Collor ao de } \\
\text { Lula }\end{array}$ & $\begin{array}{c}\text { JACOMELI, Mara Regina } \\
\text { Martins (2011) }\end{array}$ & Revista Exitus \\
\hline & $\begin{array}{l}\text { Políticas públicas e formação de } \\
\text { professores sob a perspectiva da } \\
\text { racionalidade comunicativa: da } \\
\text { ingerência tecnocrata à construção } \\
\text { da autonomia profissional }\end{array}$ & BEGO, Amadeu Moura (2016) & $\begin{array}{l}\text { Educação \& } \\
\text { Formação }\end{array}$ \\
\hline \multirow{8}{*}{$\begin{array}{l}\text { Prática e } \\
\text { Concepção } \\
\text { Docente }\end{array}$} & $\begin{array}{l}\text { O livro didático e suas implicações } \\
\text { na prática do professor nas escolas } \\
\text { públicas de Guajará-mirim }\end{array}$ & $\begin{array}{l}\text { APARECIDA Nechi Verceze, } \\
\text { Rosa Maria; MOREIRA } \\
\text { Silvino, Eliziane França (2010) }\end{array}$ & Práxis Educacional \\
\hline & $\begin{array}{l}\text { Práxis pedagógica e professores } \\
\text { intelectuais: refletindo as tensões e } \\
\text { concepções da formação/prática } \\
\text { docente }\end{array}$ & $\begin{array}{l}\text { FREITAS, S. Maria Auxiliadora } \\
(2010)\end{array}$ & Práxis Educacional \\
\hline & $\begin{array}{l}\text { A abordagem da ação crítica e a } \\
\text { epistemologia da práxis pedagógica }\end{array}$ & GENÚ, Marta Soares (2018) & $\begin{array}{c}\text { Educação \& } \\
\text { Formação } \\
\end{array}$ \\
\hline & $\begin{array}{l}\text { Didática: uma esperança para as } \\
\text { dificuldades pedagógicas do ensino } \\
\text { superior? }\end{array}$ & $\begin{array}{c}\text { SANTORO Franco, Maria } \\
\text { Amélia (2013) }\end{array}$ & Práxis Educacional \\
\hline & $\begin{array}{l}\text { O ensino de nível superior no Brasil } \\
\text { e as competências docentes: um } \\
\text { olhar reflexivo sobre esta prática }\end{array}$ & $\begin{array}{c}\text { CAVALCANTI Valente, Geilsa } \\
\text { Soraia; VIANA, Ligia de } \\
\text { Oliveira }(2010) \\
\end{array}$ & Práxis Educacional \\
\hline & $\begin{array}{l}\text { Espaço poético como tradução } \\
\text { didática: Bachelard e a imagem da } \\
\text { casa }\end{array}$ & $\begin{array}{c}\text { DINARTE, Luiz Daniel } \\
\text { Rodrigues; CORAZZA, Sandra } \\
\text { Mara (2016) }\end{array}$ & $\begin{array}{l}\text { Educação \& } \\
\text { Formação }\end{array}$ \\
\hline & $\begin{array}{l}\text { Os conceitos de concepção, } \\
\text { percepção, representação e crença } \\
\text { no campo } \begin{array}{l}\text { educacional: } \\
\text { similaridades, diferenças } \\
\text { implicações para a pesquisa }\end{array} \\
\end{array}$ & $\begin{array}{l}\text { MATOS, Daniel Abud Seabra; } \\
\text { JARDILINO, José Rubens Lima } \\
\text { (2016) }\end{array}$ & $\begin{array}{l}\text { Educação \& } \\
\text { Formação }\end{array}$ \\
\hline & $\begin{array}{l}\text { Valores, educação infantil e } \\
\text { desenvolvimento moral: concepções } \\
\text { dos professores }\end{array}$ & $\begin{array}{c}\text { LIMA, Juliana dos Santos; } \\
\text { SANTOS, Gilberto Lima dos. } \\
(2018)\end{array}$ & $\begin{array}{l}\text { Educação \& } \\
\text { Formação }\end{array}$ \\
\hline \multirow{4}{*}{$\begin{array}{l}\text { Currículo e } \\
\text { Avaliação } \\
\text { Educacional }\end{array}$} & $\begin{array}{l}\text { Inovação pedagógica e ortodoxia } \\
\text { curricular }\end{array}$ & FINO, Carlos Nogueira (2016) & $\begin{array}{l}\text { Revista Tempos e } \\
\text { Espaços em } \\
\text { Educação } \\
\end{array}$ \\
\hline & $\begin{array}{l}\text { Non-affirmative curriculum theory } \\
\text { in a cosmopolitan era? }\end{array}$ & ULJENS, Michael (2016) & $\begin{array}{l}\text { Revista Tempos e } \\
\text { Espaços em } \\
\text { Educação } \\
\end{array}$ \\
\hline & $\begin{array}{l}\text { As avaliações estandartizadas e o } \\
\text { papel do Exame Nacional do Ensino } \\
\text { Médio (ENEM) na etapa final da } \\
\text { Educação Básica }\end{array}$ & $\begin{array}{l}\text { CARNEIRO, Verônica Lima } \\
\text { (2012) }\end{array}$ & Revista Exitus \\
\hline & $\begin{array}{l}\text { Avaliação da aprendizagem no } \\
\text { ensino superior: aspectos históricos }\end{array}$ & $\begin{array}{c}\text { SOUZA, Ana Maria de Lima } \\
\text { (2012) }\end{array}$ & Revista Exitus \\
\hline \multirow{2}{*}{$\begin{array}{l}\text { Gênero e } \\
\text { Educação }\end{array}$} & $\begin{array}{l}\text { Como as escolas educam corpos nas } \\
\text { práticas pedagógicas? }\end{array}$ & DIAS, Alfrancio Ferreira (2014) & $\begin{array}{l}\text { Revista Tempos e } \\
\text { Espaços em } \\
\text { Educação } \\
\end{array}$ \\
\hline & $\begin{array}{l}\text { A crítica feminista à ciência e } \\
\text { contribuição à pesquisa nas ciências } \\
\text { humanas }\end{array}$ & $\begin{array}{l}\text { CRUZ, Maria Helena Santana } \\
\text { (2014) }\end{array}$ & $\begin{array}{l}\text { Revista Tempos e } \\
\text { Espaços em } \\
\text { Educação }\end{array}$ \\
\hline
\end{tabular}




\begin{tabular}{|c|c|c|c|}
\hline & $\begin{array}{l}\text { Pedagogia da corporeidade: o } \\
\text { decifrar e o subjetivar na educação }\end{array}$ & $\begin{array}{l}\text { GOMES-DA-SILVA, Pierre } \\
\text { Normando (2014) }\end{array}$ & $\begin{array}{l}\text { Revista Tempos e } \\
\text { Espaços em } \\
\text { Educação }\end{array}$ \\
\hline \multirow{3}{*}{$\begin{array}{l}\text { Aprendizagem } \\
\text { escolar }\end{array}$} & $\begin{array}{l}\text { A formação de modelos mentais na } \\
\text { sala de aula }\end{array}$ & $\begin{array}{c}\text { SOUZA, Edilson Sérgio } \\
\text { Ramalho de (2013) }\end{array}$ & Revista Exitus \\
\hline & $\begin{array}{l}\text { A culpabilidade pelo fracasso } \\
\text { escolar e a interface com os } \\
\text { "problemas de aprendizagem" em } \\
\text { discurso }\end{array}$ & $\begin{array}{c}\text { PEREIRA, Anderson Carvalho; } \\
\text { RIBEIRO, Carme Sandra de } \\
\text { Jesus (2017) }\end{array}$ & $\begin{array}{l}\text { Educação \& } \\
\text { Formação }\end{array}$ \\
\hline & $\begin{array}{l}\text { Desempenho escolar } \\
\text { vulnerabilidade social }\end{array}$ & $\begin{array}{l}\text { CALEJON, Laura Marisa } \\
\text { Carnielo (2011) }\end{array}$ & Revista Exitus \\
\hline \multirow{2}{*}{$\begin{array}{l}\text { Tecnologia } \\
\text { Digital e } \\
\text { Educação }\end{array}$} & $\begin{array}{l}\text { A aprendizagem ubíqua na educação } \\
\text { aberta }\end{array}$ & SANTAELLA, Lucia (2014) & $\begin{array}{l}\text { Revista Tempos e } \\
\text { Espaços em } \\
\text { Educação }\end{array}$ \\
\hline & $\begin{array}{l}\text { O uso de dispositivos móveis no } \\
\text { contexto educativo: análise de teses } \\
\text { e dissertações nacionais }\end{array}$ & $\begin{array}{l}\text { ALMEIDA, Rosiney Rocha; } \\
\text { ARAUJO Jr, Carlos Araújo } \\
\text { Fernando de (2013) }\end{array}$ & $\begin{array}{l}\text { Revista Tempos e } \\
\text { Espaços em } \\
\text { Educação } \\
\end{array}$ \\
\hline $\begin{array}{l}\text { Educação } \\
\text { Ambiental }\end{array}$ & $\begin{array}{l}\text { Ambiente, Educação } \\
\text { Interculturalidade }\end{array}$ & $\begin{array}{l}\text { RAMOS, Maria da Conceição } \\
\text { Pereira (2012) }\end{array}$ & $\begin{array}{l}\text { Revista Tempos e } \\
\text { Espaços em } \\
\text { Educação }\end{array}$ \\
\hline
\end{tabular}

FONTE: Elaboração dos autores (2020).

A partir da categoria Formação e Competência Docente foi possível perceber que nas últimas décadas pesquisas na área de educação vem sinalizando que estudiosos/as têm se debruçado em torno de tais questões (GATTI, 2001; LIBÂNEO, 2015). Nas pesquisas analisadas nesse estudo tal fenômeno também foi perceptível, se configurando como a categoria com maior quantidade de textos, correspondendo a 20,9\%. De acordo com Corradini e Mizukami (2011) ao refletir o papel do/a docente na contemporaneidade é necessário que haja um investimento maior, favorecendo dessa maneira uma formação com maior qualidade.

Outros estudos ressaltam a importância de se pensar a formação docente inicial, mas que sejam reforçadas as políticas públicas de formação continuada, considerando que é exatamente o caráter contínuo que contribui de maneira significativa no desenvolvimento das competências docentes (MARIANO, 2012; RODRÍGUEZ, 2013; MORORÓ, 2017).

As pesquisas apontam que a formação de professores/as é compreendida enquanto espaço de construção da identidade, de descoberta, de mudança, de transformação, de vida, de trocas de experiências. É um mergulho na gênese do conhecimento, seja discorrer acerca da formação de maneira mais específica, como por exemplo, professores/as para trabalhar na Educação Infantil, na Educação de Jovens e Adultos, professores/as de Matemática, dentre outras, seja pensar a formação de forma mais ampla (MOURA, 2010; SECKEL; FONT, 2015; FONT; BREDA, 2015).

De acordo com Rodríguez (2013, p. 84) refletir sobre tais temáticas é reconhecer "La promoción del debate acerca de los saberes y haceres entre los propios profesores es un aporte al desarrollo profesional entre pares y favorece el tránsito desde sus tradicionales prácticas aisladas y solitarias hacia el desarrollo de prácticas colaborativas". 
O desenvolvimento de competências e, por conseguinte, o das habilidades por elas abarcadas, não é algo distanciado da realidade, pois pressupõe tanto a análise da prática vivida no âmbito da docência quanto a análise reflexiva dos problemas concretos que permeiam e complexificam a vida profissional cotidiana (PEREZ, 2005; TANCREDI; REALI, 2011). Nesse sentido, Mororo (2017) argumenta que seja durante a formação inicial ou continuada a maneira como compreendemos determinados conteúdos vai ser imprescindível para o desenvolvimento das competências que são exigidas dos/as docentes.

A partir das análises é possível inferir que a investigação dessas temáticas tem possibilitado identificar um percurso de pesquisa relacionado formação e competências de professores/as, desenvolvido com características próprias, mas em sintonia com uma tendência internacional no âmbito das pesquisas sobre a formação e as competências docentes.

No campo de História da Educação foi possível agrupar os estudos de Razzini (2010), Boto (2009), Sampaio (2009), Smyth; Hamel (2016), Banfield; Haduntz; Maisuria (2016), e Silva; Francischini (2012). Seis estudos compõem essa categoria, o que representa 13,95\% das produções levantadas, que trazem como discussão aspectos históricos marcantes do contexto educacional.

Retratando os aspectos históricos na perspectiva da educação infantil, Boto (2009, p.119) procurou "identificar indícios relativos aos modos de ver a criança e sua educação" no âmbito da Renascença, através de revisão bibliográfica da literatura em textos da época. Já Silva; Francischini (2012) propuseram uma reflexão acerca da história do assistencialismo infantil no Brasil, enfatizando a criação das políticas públicas voltadas para a modalidade de Educação Infantil, como percurso histórico, os autores analisaram textos que retratavam o século XVI, quando não existia uma atenção especial para as crianças, e documentos legislativos que deram início ao direcionamento de práticas relacionadas à educação infantil, assim como as concepções que originaram a modalidade educacional, além da criação de creches e pré-escolas.

Com foco também nos aspectos históricos, o estudo de Sampaio (2009, p.13) tratou da trajetória da Educação de Jovens e Adultos (EJA) no Brasil, propondo uma discussão sobre "as relações complexas entre Estado, instituições não governamentais, movimentos sociais e os fatores econômicos, ideológicos, políticos e sociais, que constituem essa história”. Já o estudo de Razzini (2010) buscou através de uma pesquisa bibliográfica analisar as fases distintas pelas quais se configurou a disciplina de Português na perspectiva do ensino secundário no Brasil, dentro do recorte temporal do século XIX até a década de 1940.

No que diz respeito à história de formação de professores, o estudo de Smyth; Hamel (2016) escrito em língua estrangeira objetivou traçar os aspectos históricos dessa formação em território 
canadense, com recorte temporal do século XV até a atualidade. Também escrito em língua estrangeira, no estudo de Banfield; Haduntz; Maisuria (2016) os pesquisadores propuseram uma discussão acerca do neoliberalismo no âmbito universitário, considerando a existência de tensão entre o impulso da liberdade e a renúncia aos poderes restritivos (igreja, estado e capital).

Em Políticas Públicas Educacionais, foi possível agrupar os estudos de Lara (2016), Carneiro (2012), Matos; Mendes (2014), Tancredi (2013), Pereira (2018), Jacomeli (2011), Bego (2016). Sete estudos compõem essa categoria, representando $16,28 \%$ das produções que foram levantadas, que propõem discussões sobre as políticas públicas educacionais.

Estudos como o de Bego (2016) e Tancredi (2013) direcionaram suas abordagens para as políticas públicas de formação de professores no Brasil, tanto no âmbito da universidade com exemplo do Pibid, quanto nas Diretrizes e Bases da Educação Nacional em vigência no país.

Na perspectiva da educação inclusiva, Carneiro (2012, p.81) propôs em seu estudo uma reflexão sobre sua inserção na educação infantil, "considerando a educação inclusiva como um modelo referendado pelas políticas públicas”, entretanto, algo ainda distante da realidade escolar. Já Matos; Mendes (2014) através de uma revisão da literatura procuraram construir reflexões, considerações e até críticas sobre a proposta de inserção da inclusão no ambiente escolar, a partir da implementação das políticas públicas educacionais, considerando a diversidade e o próprio histórico de surgimento da educação inclusiva.

No estudo de Pereira (2018), a preocupação está centrada na compreensão do processo de ensino e aprendizagem na Educação de Jovens e Adultos (EJA) em situação de privação de liberdade no Brasil, a pesquisa foi desenvolvida a partir da análise do conteúdo e quatorze Panos Estaduais de Educação em Prisões (PEEPs), com foco no planejamento das ações para essa modalidade de ensino e as contradições presentes na prática desenvolvida no sistema penitenciário.

O estudo de Jacomeli (2011, p.119) procurou refletir sobre "as políticas públicas para a educação brasileira, a partir do governo Collor até o de Lula". Refletindo também acerca das políticas de redução da desigualdade social, Lara (2016) propõe uma discussão sobre as políticas sociais na América Latina, diante da complexidade das diversas formas de desigualdade, dos princípios e fundamentos que a sustenta, como o capitalismo monopolista, e o desacerbado papel do Estado frente à compreensão de desigualdade sociocultural.

As reflexões sobre o Currículo ${ }^{1}$ e Avaliação Educacional são relativamente incipientes no Brasil (GATTI, 2012). Dessa maneira, as pesquisas analisadas nesse estudo parte do princípio de

\footnotetext{
${ }^{1}$ Sobre as discussões sobre currículo ler os trabalhos de Rudd e Goodson (2016), Uljens (2016), Pacheco e Sousa (2016), Morgado (2016), Moreira e Silva Junior (2016), Kovacs e Tinoca (2017), Fino (2016), Sousa (2016), Pedro (2017), Barbosa e Cassiani (2017), Menezes e Dias (2017), Campani e Silva (2019) e Rocha (2020).
} 
que os currículos não são conteúdos prontos a serem passados aos alunos. São uma construção e seleção de conhecimentos e práticas produzidas em contextos concretos e em dinâmicas sociais, políticas e culturais, intelectuais e pedagógicas (FINO, 2016; ULJENS, 2016).

Uljens (2016) problematiza o conceito de currículo suscitando questões a serem pensadas, como por exemplo, a ideia de um currículo nacional e global e, portanto, homogeneizante. $\mathrm{O}$ autor se utilizar das teorias contemporâneas da educação, para defender um currículo plural e que responda aos desafios atuais. Já Fino (2016), discute a impossibilidade de o currículo poder constituir-se em fonte de transgressão, assumindo-se, pelo contrário. Nascimento e Rios (2020) argumentam sobre a necessidade de se estruturar o currículo de acordo com a realidade dos sujeitos que estarão de alguma maneira atingidos por ele.

Ao discorrer sobre a avaliação Souza (2012) ressalta que o interesse deste estudo se coloca na dimensão histórica da avaliação da sala de aula, tendo como foco as práticas de avaliação no ensino superior. A autora conclui que ainda hoje predominam práticas de avaliação mais tradicionais do que transformadoras. Carneiro (2012), a partir de um levantamento bibliográfico discute a elaboração e implementação das avaliações estandartizadas, cujo foco é o Exame Nacional do Ensino Médio - ENEM.

A partir das análises, é possível evidenciar que os/as autores/as problematizam a maneira como as práticas de currículo e os processos avaliativos são desenvolvidos nas diferentes instâncias do fazer pedagógico, ao tempo em que salientam sobre a relevância de tais discussões não só durante a formação docente, mas na prática pedagógica cotidiana.

Estudos como os de Lima e Santos (2018), Genu (2018), Dinarte e Corazza (2016), Matos e Jardilino (2016), Franco (2013), Verceze e Silvino (2010), Freitas (2010) e Valente e Viana (2010), se preocuparam em problematizar as práticas e as concepções docentes desde a Educação Infantil até o Ensino Superior considerando a relação entre o pensar e o construir de novas possibilidades referentes ao trabalho docente. Esses oito estudos em tela representam 18,6\% do total dos artigos levantados.

A compreensão de como os professores da Educação Infantil concebem os valores em relação às suas práticas pedagógicas e ao desenvolvimento moral das crianças constituiu-se no objetivo proposto por Lima e Santos (2018). Neste estudo evidenciou-se que por muitas vezes, os docentes são enredados ou impossibilitados de desenvolver estratégias ou atividades que potencializem o desenvolvimento integral da criança principalmente no que tange às ações voltadas à leitura e à escrita. Dessa maneira, "o desenvolvimento moral é invisibilizado, em certa medida" (LIMA; SANTOS, 2018, p. 167). 
A partir da análise sobre os conceitos de concepção, percepção e crença, Matos e Jardilino (2016) revelam que esses termos indicam a maneira como as pessoas percebem, avaliam e agem com relação a um determinado fenômeno pesquisado. Atribui-se aqui, partindo de um acordo mínimo entre os pares sobre o significado desses conceitos, há necessidade de uma constante vigilância epistemológica. Destarte, trata-los como sinônimos, segundo os autores, resultará em um encadeamento de equívocos na propagação dos resultados das pesquisas.

Partindo da concepção filosófica calcada na base materialista dialética, Freitas (2010) situa os embates contemporâneos sobre o significado de práxis, articulando essas proposições a práxis docente e buscando alternativas para que o professor seja capaz de refletir sobre seus discursos e suas práticas. Atentar para essa questão, segundo a autora, se faz necessário já que toda a reflexão deve situar as circunstâncias concretas, ligadas ao contexto histórico, social, político e econômico, apresentando assim a possibilidade de contribuir para a formação de sujeitos sociais instituinte.

O estudo de Genu (2018) propôs a sistematização pedagógica como possibilidade teóricoprática a ser desenvolvida pelo docente. A partir desse aspecto considera-se que "é a apropriação epistemológica por parte do professor que promove a ação do ensinar aprender mais do que o domínio de técnicas pedagógicas" (GENU, 2018, p. 55).

Verceze e Silvino (2010) no seu estudo, refletem sobre o livro didático e a sua utilização a partir da perspectiva da língua como sistema de representação do mundo que está presente em todas as outras áreas do conhecimento buscando verificar se esse livro didático abarca informações e conceitos capazes de condizerem à aprendizagem para a construção de conhecimentos.

As possibilidades da Didática no espaço contraditório e tenso de ensinar e aprender na Universidade contemporânea, é a temática apresentada por Franco (2013). O estudo alvitrou analisar a proposta europeia no que tange a formação didática a docentes desse nível de ensino. Valente e Viana (2010) também propõem estudos voltados para o Ensino Superior. O estudo objetiva refletir sobre a qualidade do ensino de graduação, no que se refere às áreas de competência do enfermeiro professor, numa perspectiva do ensino como prática reflexiva, utilizando a investigação para subsidiar a tomada de decisão e a resolução de problemas.

Dinarte e Corazza (2016) estabelecem um estudo a partir da invenção de um problema envolvendo o espaço poético a partir de uma obra de Gaston Bachelard e a didática que condicionam tal cruzamento.

Comumente a discussão sobre gênero e as temáticas que derivam desse assunto não são trabalhadas em sala de aula. Percebe-se a ausência dessa temática nos cursos de formação docente. 
Contudo, nas últimas décadas tem sido notório um crescimento em pesquisas e estudos que, de alguma maneira, fazem com que tais discussão possam emergir.

Ao se debruçar sobre as temáticas de gênero, feminismos e suas intersecções, Cruz (2014) apresenta as contribuições trazidas pela epistemologia feminista à ciência e à pesquisa nas ciências humanas e sociais, particularmente na área da educação. A autora enfatiza a relevância de tais estudos, ressaltando que os mesmos favorecem realizar pesquisas e analisar diferentes aspectos da sociedade.

Dias (2014) problematiza, a partir de uma revisão da literatura, como os corpos de meninos e meninas são educados nos espaços escolares e como os mesmos produzem as diferenças. De acordo com Dias (2014) é necessário a implementação de um princípio de coeducação, possibilitando dessa maneira, a ampliação das relações de gênero no âmbito da escola.

A pesquisa de Gomes-da-Silva (2014), apresenta o conceito de corporeidade desenvolvido pelo Laboratório de Estudos e Pesquisas em Corporeidade, Cultura e Educação - Universidade Federal de Paraíba (UFPB) e a partir desse estudo propõe metodologias de intervenção que torna as experiências perceptivo-motoras refletidas como o epicentro da aprendizagem.

Incluímos três estudos $(6,98 \%)$, com relação ao total de artigos levantados, na categoria aprendizagem escolar. Calejon (2011) problematiza a dinâmica do desenvolvimento entre outros conceitos, pautados pelo Enfoque Histórico-Cultural e das concepções sobre aprendizagem como premissas que permitem conceber de forma mais conveniente o desempenho escolar de sujeitos em situação de vulnerabilidade social.

O estudo de Souza (2013) se propõe a discutir as formas que a dinâmica de formação de modelos mentais, podem ser vantajosas para o ensino-aprendizagem. Nesta perspectiva, as diversas imagens mentais acomodadas constituem um modelo mental que respalda explicações durante as tarefas de ensino, ou seja, "os modelos mentais estão relacionados à própria capacidade de compreensão do sujeito" (SOUZA, 2013, p. 170).

Pereira e Ribeiro (2017) evidenciam um estudo pautado a partir das formas de falas de professores e pais de alunos a respeito do fracasso escolar, associando-o aos "problemas de aprendizagem" e desta forma "marcada pela fronteira e pelo embate de dizeres que sinaliza efeitos de sentido (de interpretação) alusivo a discursos do cotidiano" (PEREIRA; RIBEIRO, 2017, p. 96).

No campo das tecnologias digitais apenas duas produções $(4,65 \%)$ se propuseram a analisar e descrever suas influências no âmbito educacional, como Santaella (2014, p.15) que procurou "discutir o papel que a aprendizagem ubíqua pode desempenhar no contexto de práticas e recursos educacionais abertos" na perspectiva de uma educação em rede. Já Almeida (2013) que se propôs 
analisar o estado do conhecimento sobre a utilização de dispositivos móveis no ensino formal brasileiro a partir do catálogo de dissertações e teses da CAPES.

Na categoria Educação Ambiental, o estudo de Ramos (2012) evidencia a problemática que se refere ao ecodesenvolvimento, ao desenvolvimento sustentável e as diferentes dimensões da sustentabilidade. Não obstante, considera-se os desafios atuais e culturais dos migrantes e refugiados ambientais face as mudanças climáticas e catástrofes ambientais. "Trata-se de considerar importantes aspectos sociais e ético da educação, da economia, da sociedade e da responsabilidade social das organizações e dos cidadãos, visando a obtenção de um desenvolvimento sustentável que respeite o ambiente natural e melhore a qualidade de vida" (RAMOS, 2012, p. 28).

\section{Considerações}

A presente revisão de literatura permitiu delinear um panorama das produções mais citadas em distintas áreas do conhecimento em educação, entre 2005 e 2018, num total de 43 artigos publicados nas Revistas Tempos e Espaços em Educação, do Programa de Pós-Graduação em Educação - PPGED, da Universidade Federal de Sergipe - UFS; Práxis Educacional, Programa de Pós-Graduação em Educação - PPGEd, da Universidade Estadual do Sudoeste da Bahia - UESB; Exitus, Programa de Pós-graduação em Educação da Universidade Federal do Oeste do Pará UFOPA e; Educação e Formação, do Programa de Pós-Graduação em Educação - PPGE, da Universidade Estadual do Ceará - UECE, filiados ao Fórum de Editores de Periódicos da Área de Educação - FEPAE/ANPED-Norte/Nordeste.

A diversidade de temáticas nos artigos analisados apresenta indicadores de complexidade das demandas em pesquisa na área de educação, com especial atenção as questões que dizem respeito formação e competência docente (09 artigos, 20,9\%), história da educação (06 artigos, 13,95\%), políticas públicas educacionais (07 artigos, 16,28\%), prática e concepção docente (08 artigos,18,6\%), currículo e avaliação educacional (04 artigos, 9,30 \%), gênero e educação (03 artigos, 6,98\%), aprendizagem escolar (03 artigos, 6,98\%), Tecnologia Digital e Educação (02 artigos, 4,65\%) e educação ambiental (01 artigo, 2,36\%).

Considerando os dados a partir dos artigos analisados é possível inferir que os estudos com maior notoriedade se concentram nas áreas de formação e competência docente e políticas públicas educacionais. Referente a primeira categoria é possível dizer que se trata do entendimento dos/as pesquisadores às questões inerentes ao fazer profissional da própria categoria.

Esse quantitativo se constitui enquanto reflexo de maior compreensão da docência em suas distintas áreas de atuação, que só se torna exequível por meio de investimento em políticas públicas 
educacionais. É possível dizer que de nada, ou quase nada, adiantaria discorrer acerca da formação e competência docentes em Educação de Jovens e Adultos, Educação Infantil, Inclusiva, Ambiental, Tecnológica, sem que sejam asseguradas políticas públicas educacionais que viabilizem e assegurem o fazer docente que leve em consideração práticas de currículo e avaliação a partir dos distintos contextos nos quais os sujeitos do fazer pedagógicos estão inseridos.

A preocupação com aprendizagem escolar, foi um dos elementos que mereceu atenção dos estudos por nós analisados. As pesquisas ressaltam a importância de se entender a maneira mais conveniente do desempenho escolar de sujeitos em situação de vulnerabilidade social, criando estratégias de ensino para que a aprendizagem tenha sentido e significado por meio de uma práxis pedagógica contextualizada.

A partir das análises é possível perceber o quanto as pesquisas em educação têm se debruçado no sentido de compreender de que maneira as questões contemporâneas, como por exemplo, a equidade de gênero, corpo, sexualidade, tecnologia, meio ambiente, dentre outras, influenciam e são influenciadas pelas práticas pedagógicas e, portanto, precisam necessariamente serem suscitadas e problematizadas em pesquisas e no fazer cotidiano da escola.

Concluindo, afirmamos que o desenvolvimento de pesquisas em educação e seus diferentes campos de atuação, por meio das referidas revistas, é de extrema importância, uma vez que assegura a expansão do conhecimento de maneira confiável. Além disso, é possível assegurar que tais pesquisas ratificam o Nordeste e o Norte do Brasil enquanto territórios produtores e difusores do conhecimento em educação.

\section{REFERÊNCIAS}

ALMEIDA, R. R.; ARAÚJO Jr, C. A. F. O Uso de Dispositivos Móveis no Contexto Educativo: Análise de Teses e Dissertações Nacionais. Revista Tempos e Espaços em Educação, v. 6, n. 11, 25-36, 2013. Disponível em: <https://doi.org/10.20952/revtee.v0i0.2538>. Acesso em: 17 abr. 2020 .

BANFIELD, G.; HADUNTZ, H.; MAISURIA, A. The (im)possibility of the intellectual worker inside the neoliberal university. Educação \& Formação, v. 1, n. 3 set/dez, p. 3-19, 1 set. 2016. Disponível em: 〈https://doi.org/10.25053/edufor.v1i3.1974〉. Acesso em: 17 abr. 2020.

BEGO, A. Políticas públicas e formação de professores sob a perspectiva da racionalidade comunicativa: da ingerência tecnocrata à construção da autonomia profissional. Educação \& Formação, v. 1, n. 2 mai/ago, p. 3-24, 2 maio 2016. Disponível em: <https://doi.org/10.25053/edufor.v1i2.1864>. Acesso em: 17 abr. 2020. 
BOTO, C. Civilizar a infância na Renascença: estratégia de distinção de classe. Revista Tempos e Espaços em Educação. Disponível em: <https://doi.org/10.20952/revtee.v0i0.2208>. Acesso em: 17 abr. 2020.

BRITO, R. S.; PRADO, J. R.; NUNES, C. P. As condições de trabalho docente e o pós-estado de bem-estar social. Revista Tempos e Espaços em Educação, v. 10, n. 23, p. 165-174, 2017. DOI: https://doi.org/10.20952/revtee.v10i23.6676

CALEJON, Laura Marisa Carnielo. Desempenho escolar e vulnerabilidade social. Revista Exitus, v. 1, n. 1, jul./dez. 2011, p. 149-164. ISSN 2237-9460. Disponível em:

<http://www.ufopa.edu.br/portaldeperiodicos/index.php/revistaexitus/article/view/214> Acessado em: 17 abr. 2020.

CARBONE CARNEIRO, Relma Urel. Educação inclusiva na educação infantil. Revista Práxis Educacional, Vitória da Conquista, v. 8, n. 12, p. 81-95, mar. 2012. ISSN 2178-2679. Disponível em: 〈http://periodicos2.uesb.br/index.php/praxis/article/view/688>. Acesso em: 17 abr. 2020.

CARNEIRO, Verônica Lima. As avaliações estandartizadas e o papel do Exame Nacional do Ensino Médio (ENEM) na etapa final da Educação Básica. Revista Exitus, v. 2, n. 1, jan./jun. 2012, p. 217-230. ISSN 2237-9660. Disponível em:

<http://www.ufopa.edu.br/portaldeperiodicos/index.php/revistaexitus/article/view/84> Acesso em: 17 abr. 2020.

CORRADINI, Suely Nercessian; MIZUKAMI, Maria da Graça Nicoletti. Formação Docente: O profissional da sociedade contemporânea. Revista Exitus, v. 1, n. 1, jan./jun. 2011, p. 53-62.

ISSN 2237-9660. Disponível em:

<http://www.ufopa.edu.br/portaldeperiodicos/index.php/revistaexitus/article/view/205> Acesso em: 17 abr. 2020.

COSTA, Ana Sheila Fernandes; AKKARI, Abdeljalil; SILVA, Rossana Valéria Souza. Educação básica no Brasil: políticas públicas e qualidade. Revista Práxis Educacional, Vitória da Conquista, v.7, n. 11, jun./dez. 2011. Disponível em: http://periodicos2.uesb.br/index.php/praxis/article/view/666. Acesso em: 14 fev. 2020.

CRUZ, M. H. S. A Crítica Feminista à Ciência e Contribuição à Pesquisa nas Ciências Humanas. Revista Tempos e Espaços em Educação, v. 7, n. 12, p.15-28, 2014. Disponível em: <https://doi.org/10.20952/revtee.v0i0.2949 >. Acesso em: 17 abr. 2020.

DIAS, Alfrancio Ferreira. Como as escolas educam corpos nas práticas pedagógicas?. Revista Tempos e Espaços em Educação, v. 7, n. 12, p.15-28, 2014. Disponível em: <https://doi.org/10.20952/revtee.v0i0.2958>. Acesso em: 17 abr. 2020

DIAS, Alfrancio Ferreira. F.; AMORIM, Simone. Body, gender and sexuality in teacher training: a meta-analysis. Educação em Revista, n. 56, abr./jun. 2015, p. 193-206. ISSN 1984-0411. Disponível em: <http://www.scielo.br/scielo.php?script=sci_arttext\&pid=S010440602015000200193\&lng= en\&nrm=isso>. Acesso em: 22 abr. 2020.

DIAS, A. F.; CARDOSO, H. M.; SANTOS, A. L.; MENEZES, C. A. A.; RIOS, P. P. S. Schooling and subversions of gender. Revista Tempos e Espaços em Educação, v. 10, n. 22, p. 83-92, 2017. DOI: https://doi.org/10.20952/revtee.v10i22.6433 
DINARTE, L. D.; CORAZZA, S. Espaço poético como tradução didática: Bachelard e a imagem da casa. Educação \& Formação, v. 1, n. 2 mai/ago, p. 135-148, 2 maio 2016. Disponível em: <https://doi.org/10.25053/edufor.v1i2.1618>. Acesso em: 17 abr. 2020.

ECHER, Isabel Cristina. A revisão de literatura na construção do trabalho científico. Revista Gaúcha de Enfermagem. Porto Alegre, v. 22, n. 2 (jul. 2001), p. 5-20, 2001. Disponível em: https://seer.ufrgs.br/RevistaGauchadeEnfermagem/article/view/4365. Acesso em: 20 Abr. 2020.

EUGÊNIO, Benedito Gonçalves. O currículo na educação de jovens e adultos: entre o formal e o cotidiano numa escola municipal em belo horizonte. Revista Práxis Educacional, Vitória da Conquista, v. 4, n. 4, jan./jun. 2008. Disponível em:

https://periodicos2.uesb.br/index.php/praxis/article/view/570. Acesso em: 19 abr.2020.

FIGUEIREDO FILHO, Dalson Brito. et al. O que é, para que serve e como se faz uma metaanálise? Teoria \& Pesquisa, v. 23, n. 2, jul./dez. 2014, p. 205-228. ISSN 2236-0107. Disponível em: 〈www.teoriaepesquisa.ufscar.br/index.php/tp/article/view/401/272>. Acesso em: $22 \mathrm{abr}$. 2020 .

FINO, C. N. Inovação Pedagógica e Ortodoxia Curricular. Revista Tempos e Espaços em Educação, v. 9, n. 18, p. 13-22, 2016. Disponível em: <https://doi.org/10.20952/revtee.v9i18.4959>. Acesso em: 17 abr. 2020.

FONT, Vicenç; BREDA, Adriana. Competências profissionais na formação inicial de professores de matemática. Práxis Educacional, [S.1.], v. 11, n. 19, p. 17-34, ago. 2015. ISSN 2178-2679. Disponível em: <http://periodicos2.uesb.br/index.php/praxis/article/view/818>. Acesso em: 17 abr. 2020.

FRANCO, Maria Amélia Santoro. Didática: uma esperança para as dificuldades pedagógicas do ensino superior?. Revista Práxis Educacional, Vitória da Conquista, v. 9, n. 15, p. 147-166, set. 2013. ISSN 2178-2679. Disponível em: <http://periodicos2.uesb.br/index.php/praxis/article/view/750>. Acesso em: 17 abr. 2020.

FREITAS, Maria Auxiliadora. Práxis pedagógica e professores intelectuais: refletindo as tensões e concepções da formação/prática docente. Revista Práxis Educacional, Vitória da Conquista, v. 1, n. 1, p. 135-150, out. 2010. ISSN 2178-2679. Disponível em:

<http://periodicos2.uesb.br/index.php/praxis/article/view/485>. Acesso em: 17 abr. 2020.

FULLAGAR, S. A physical cultural studies perspective on physical (in)activity and health inequalities: the biopolitics of body practices and embodied movement. Revista Tempos e Espaços em Educação, v. 12, n. 28, p. 63-76, 1 jan. 2019. DOI:

https://doi.org/10.20952/revtee.v12i28.10161

GATTI, B. A. Implicações e perspectivas da pesquisa educacional no Brasil contemporâneo.

Cadernos de Pesquisa. 2001, n.113, pp.65-81. ISSN 0100-1574. Disponível em: http://www.scielo.br/pdf/cp/n113/a04n113.pdf. Acesso em 21 abr. 2020.

GATTI, B. A. Políticas de avaliação em larga escala e a questão da inovação educacional. SérieEstudos - Periódico do Programa de Pós-Graduação em Educação da UCDB Campo Grande, MS, n. 33, p. 29-37, jan./jul. 2012. Disponível em: https://site.ucdb.br/pesquisa-e- 
inovacao/6/periodicos-ucdb/848/revista-serie-estudos-desativado/849/publicacoes/1181/. Acesso em: 21 Abr. 2020.

GENÚ, M. A abordagem da ação crítica e a epistemologia da práxis pedagógica. Educação \& Formação, v. 3, n. 9 set/dez, p. 55-70, 3 set. 2018. Doi: https://doi.org/10.25053/redufor.v3i9.856

GOMES-DA-SILVA, P. N. Pedagogia da corporeidade: o decifrar e o subjetivar na educação. Revista Tempos e Espaços em Educação, v. 7, n. 13, p. 15-30, 2014. Disponível em: <https://doi.org/10.20952/revtee.v0i0.3255>. Acesso em: 17 abr. 2020.

JACOMELI, Mara Regina Martins. As políticas educacionais da Nova República: do governo Collor ao de Lula. Revista Exitus, v. 1, n. 1, jan./jun. 2011, p. 119-128. ISSN 2237-9660. Disponível em:

<http://www.ufopa.edu.br/portaldeperiodicos/index.php/revistaexitus/article/view/211 > Acesso em: 17 abr. 2020.

LARA, A. M. Políticas de redução da desigualdade sociocultural. Educação \& Formação, v. 1, n. 3 set/dez, p. 140-153, 1 set. 2016. Disponível em: 〈https://doi.org/10.25053/edufor.v1i3.1621〉. Acesso em: 17 abr. 2020.

LIBÂNEO, J. C. Pedagogia e pedagogos, para quê? São Paulo: Cortez, 2015.

LIMA, J.; SANTOS, G. Valores, educação infantil e desenvolvimento moral: concepções dos professores. Educação \& Formação, v. 3, n. 8 mai/ago, p. 153-170, 2 maio 2018. Disponível em: <https://doi.org/10.25053/redufor.v3i8.275>. Acesso em: 17 abr. 2020.

KOVACS, H.; TINOCA, L. Unfreeze the pedagogies: introduction of a new innovative measure in Portugal. Revista Tempos e Espaços em Educação, São Cristóvão, v. 10, n. 23, p. 73-86, 2017. Disponível em: <https://seer.ufs.br/index.php/revtee/article/view/7446>. Acesso em: 3 jan. 2020.

MARIANO, André Luiz Sena. A aprendizagem da docência no início da carreira: qual política? Quais problemas? Revista Exitus. v. 2, n. 1, jan./jun. 2012, p. 79-94. ISSN 2237-9460. Disponível em:

〈http://www.ufopa.edu.br/portaldeperiodicos/index.php/revistaexitus/article/view/67> Acessado em: 17 abr. 2020.

MATOS, Selma Norberto; MENDES, Enicéia Gonçalves. A proposta de inclusão escolar no contexto nacional de implementação das políticas educacionais. Revista Práxis Educacional, Vitória da Conquista, v. 10, n. 16, p. 35-59, maio 2014. ISSN 2178-2679. Disponível em: <http://periodicos2.uesb.br/index.php/praxis/article/view/762>. Acesso em: 17 abr. 2020.

MATOS, D.; JARDILINO, J. R. Os conceitos de concepção, percepção, representação e crença no campo educacional: similaridades, diferenças e implicações para a pesquisa. Educação \&

Formação, v. 1, n. 3 set/dez, p. 20-31, 1 set. 2016. Disponível em:

<https://doi.org/10.25053/edufor.v1i3.1893>. Acesso em 17 abr. 2020.

MARÍN, Jorge Garcia. Educación y reproducción cultural: el legado de Bourdieu. Revista Práxis

Educacional, Vitória da Conquista, v. 2, n. 2, jan./dez. 2006. Disponível em:

https://periodicos2.uesb.br/index.php/praxis/article/view/513. Acesso em: 14 abr. 2020. 
MENEZES, C. A. A; DIAS, A. F.; SANTOS, M. S. What pedagogical innovation does queer pedagogy propose to the school curriculum?. Revista Práxis Educacional, v. 16, n. 37, p. 241258, jan. 2020. Disponível em: 〈http://periodicos2.uesb.br/index.php/praxis/article/view/6168>. Acesso em: 17 abr. 2020. doi: https://doi.org/10.22481/praxisedu.v16i37.6168.

MORORÓ, L. A influência da formação continuada na prática docente. Educação \& Formação, v. 2, n. 4 jan/abr, p. 36-51, 2 jan. 2017. Disponível em:

<https://doi.org/10.25053/edufor.v2i4.1961> .Acesso em: 17 abr. 2020.

MOURA, Tania Maria de Melo. Formação de educadores de jovens e adultos: realidade, desafios e perspectivas atuais. Revista Práxis Educacional, Vitória da Conquista, v. 5, n. 7, p. 45-72, jul. 2010. ISSN 2178-2679. Disponível em:

<http://periodicos2.uesb.br/index.php/praxis/article/view/601>. Acesso em: 17 abr. 2020.

MOREIRA, A. F.; SILVA JÚNIOR, P. M. DA. Currículo, Transgressão e Diálogo: quando Outras Possibilidades se Tornam Necessárias. Revista Tempos e Espaços em Educação, São Cristóvão, v. 9, n. 18, p. 45-54, 11. Disponivel em: <https://seer.ufs.br/index.php/revtee/article/view/4962>. Acesso em: 17 abr. de 2020.

MORGADO, J. C. O professor como decisor curricular: de ortodoxo a cosmopolita. Revista Tempos e Espaços em Educação, São Cristóvão, v. 9, n. 18, p. 55-64, 2016. Disponivel em: <https://seer.ufs.br/index.php/revtee/article/view/4964>. Acesso em: 17 abr. de 2020.

MENEZES, C. A. A; DIAS, A. F. Que inovação pedagógica a pedagogia queer propõe ao currículo escolar?. Revista Tempos e Espaços em Educação, São Cristóvão, v. 10, n. 23, p. 37 48, 2017. Disponível em: <https://seer.ufs.br/index.php/revtee/article/view/7443 >. Acesso em: 3 jan. 2020. DOI: https://doi.org/10.20952/revtee.v10i23.7443.

NASCIMENTO, L. de S.; RIOS, P. P. S. Currículo na Educação Infantil: reflexões sobre a formação docentes e infâncias. In.: RIOS, P. P. S. (org.) Pesquisa e Prática Pedagógica no Semiárido. Curitiba: CRV, 2020.

NASCIMENTO, L. F.; CAVALCANTE, M. M. D. Abordagem quantitativa na pesquisa em educação: investigações no cotidiano escolar. Revista Tempos e Espaços em Educação, v. 11, n. 25, p. 249-260, 2018. DOI: https://doi.org/10.20952/revtee.v11i25.7075

NUNES, Claudio Pinto. As ciências da educação e a prática pedagógica: sentidos atribuídos por estudantes do curso de pedagogia Revista Práxis Educacional, Vitória da Conquista, v. 8, n. 12, jan./jun. 2005. Disponível em: https://periodicos2.uesb.br/index.php/praxis/article/view/657. Acesso em: 17 abr. 2020.

OLIVEIRA, A. M.; GEREVINI, A. M.; STROHSCHOEN, A. A. G. Diário de bordo: uma ferramenta metodológica para o desenvolvimento da alfabetização científica. Revista Tempos e Espaços em Educação, v. 10, n. 22, p. 119-132, 2017. Doi:

https://doi.org/10.20952/revtee.v10i22.6429

PARASKEVA, J. M. "Brutti, Sporchi \& Cattivi": Towards a Non-Abyssal Curriculum. Revista Tempos e Espaços em Educação, v. 9, n. 18, p. 75-90, 2016.

DOI: https://doi.org/10.20952/revtee.v9i18.4966 
PACHECO, J. A.; SOUSA, J. O (pós) crítico na Desconstrução Curricular. Revista Tempos e Espaços em Educação, São Cristóvão, v. 9, n. 18, p. 65-74, 2016. Disponível em: <https://seer.ufs.br/index.php/revtee/article/view/4971>. Acesso em: 17 abr. de 2020.

PEDRO, N. Ambientes educativos inovadores: o estudo do fator espaço nas 'salas de aula do futuro’ portuguesas. Revista Tempos e Espaços em Educação, São Cristóvão, v. 10, n. 23, p. 99108, 2017. Disponível em: <https://seer.ufs.br/index.php/revtee/article/view/7448>. Acesso em: 17 abr. de 2020. DOI: https://doi.org/10.20952/revtee.v10i23.7448.

PEREIRA, A.; RIBEIRO, C. S. A culpabilidade pelo fracasso escolar e a interface com os "problemas de aprendizagem" em discurso. Educação \& Formação, v. 2, n. 5 mai/ago, p. 95-110, 2 maio 2017. Disponível em: 〈https://doi.org/10.25053/edufor.v2i5.1959>. Acesso em: 17 abr. 2020 .

PEREIRA, A. A educação de jovens e adultos no sistema prisional brasileiro: o que dizem os planos estaduais de educação em prisões?. Revista Tempos e Espaços em Educação, v. 11, n. 24, p. 245-252, 2018. Disponível em: 〈https://doi.org/10.20952/revtee.v11i24.6657〉. Acesso em: 17 abr. 2020.

PEREZ, Marcia Cristina Argenti. Infância e escolarização: discutindo a relação família, escola e as especificidades da infância na escola. Revista Práxis Educacional, Vitória da Conquista, v. 8, n. 12, jan./jun. 2012. Disponível em: http://periodicos2.uesb.br/index.php/praxis/article/view/684. Acesso em: 15 fev. 2020.

PEREZ, Maria Isabel Lopes. Competência: uma noção plástica, polissêmica e polimorfa. Revista Práxis Educacional, Vitória da Conquista, v. 1, n. 1, p. 57-65, ago. 2005. ISSN 2178-2679. Disponível em: 〈http://periodicos2.uesb.br/index.php/praxis/article/view/480>. Acesso em: 17 abr. 2020.

PINTO, E. J. S.; CARVALHO, M. E. P.; RABAY, G. As relações de gênero nas escolhas de cursos superiores. Revista Tempos e Espaços em Educação, v. 10, n. 22, p. 47-58, 2017. DOI: https://doi.org/10.20952/revtee.v10i22.6173

RAMOS, M. da C. P. Ambiente, Educação e Interculturalidade. Revista Tempos e Espaços em Educação, v. 5, n. 8, 2012. Doi: https://doi.org/10.20952/revtee.v0i0.2284

RAZZINI, M. de P. G. História da Disciplina Português na Escola Secundária Brasileira. Revista Tempos e Espaços em Educação, v. 3, n. 2, 2010. Disponível em: <https://doi.org/10.20952/revtee.v0i0.2218>. Acesso em: 17 abr. 2020.

RODRIGUEZ Linda Grace Matus. La construcción de una identidad docente, ¿un desafío para la política educativa? Revista Exitus. v. 3, n. 1, jan./jun. 2013, p. 75-87. ISSN 2237-9460.

Disponível em:

<http://www.ufopa.edu.br/portaldeperiodicos/index.php/revistaexitus/article/view/250> Acesso em: 17 abr. 2020.

RUDD, T.; GOODSON, I. F. Refraction as a tool for understanding action and educational orthodoxy and transgression. Revista Tempos e Espaços em Educação, São Cristóvão, v. 9, n. 18, p. 99-110, 2016. Disponível em: 〈https://seer.ufs.br/index.php/revtee/article/view/4968>. DOI: https://doi.org/10.20952/revtee.v9i18.4968. 
SANTAELLA, L. A aprendizagem ubíqua na educação aberta. Revista Tempos e Espaços em Educação, v. 7, n. 14, p. 15-22, 2014. Disponível em:

<https://doi.org/10.20952/revtee.v0i0.3446 >. Acesso em: 17 abr. 2020.

SAMPAIO, Marisa Narcizo. Educação de Jovens e Adultos: uma história de complexidade e tensões. Revista Práxis Educacional, Vitória da Conquista, v. 5, n. 7, p. 13-27, ago. 2009. ISSN 2178-2679. Disponível em: 〈http://periodicos2.uesb.br/index.php/praxis/article/view/600>. Acesso em: 17 abr. 2020.

SANTOS, José Jackson Reis dos. Especificidades dos saberes para a docência na educação de pessoas jovens e adultas. Revista Práxis Educacional, Vitória da Conquista, v. 6, n. 8, jan./jun. 2010. Disponível em: https://periodicos2.uesb.br/index.php/praxis/article/view/623. Acesso em: 18 abr. 2020.

SECKEL, María José; FONT, Vicenç. Competencia de reflexión en la formación inicial de profesores de matemática en Chile. Revista Práxis Educacional, Vitória da Conquista, v. 11, n. 19, p. 55-75, abr. 2015. ISSN 2178-2679. Disponível em:

<http://periodicos2.uesb.br/index.php/praxis/article/view/834>. Acesso em: 17 abr. 2020.

SILVA, Carmem Virginia Moraes da; FRANCISCHINI, Rosangela. O surgimento da educação infantil na história das políticas públicas para a criança no brasil. Revista Práxis Educacional, Vitória da Conquista, v. 8, n. 12, jan./jun. 2012. Disponível em: https://periodicos2.uesb.br/index.php/praxis/article/view/699. Acesso em: 15 fev. 2020.

SMYTH, E.; HAMEL, T. The history of initial teacher education in Canada: Québec and Ontario. Educação \& Formação, v. 1, n.1, jan/abr, p. 88-109, 4 jan. 2016. Disponível em: <https://doi.org/10.25053/edufor.v1i1.1606>. Acesso em: 17 abr. 2020.

SOUZA, Ana Maria de Lima. Avaliação da aprendizagem no ensino superior: aspectos históricos. Revista Exitus, v. 2, n. 1, jan./jun. 2012, p.231-254. ISSN 2237-9460. Disponível em:

<http://www.ufopa.edu.br/portaldeperiodicos/index.php/revistaexitus/article/view/85> Acessado em: 17 abr. 2020.

SOUZA, Edilson Sérgio Ramalho de. A formação de modelos mentais na sala de aula. Revista Exitus, v. 3, n. 1, jan./jun. 2013, p. 169-184. ISSN 2237-9660. Disponível em:

〈http://www.ufopa.edu.br/portaldeperiodicos/index.php/revistaexitus/article/view/256> Acesso em: 17 abr. 2020.

SOUSA, J. M. Repensar o currículo como emancipador. Revista Tempos e Espaços em Educação, São Cristóvão, v. 9, n. 18, p. 111-120, 2016. Disponível em:

<https://seer.ufs.br/index.php/revtee/article/view/4969>. Acesso em: 17 abr. de 2020. DOI: https://doi.org/10.20952/revtee.v9i18.4969.

SOUSA, J. M. Discutindo conceitos em torno do Currículo. Revista Tempos e Espaços em Educação, v. 10, n. 23, p. 15-26, 2017. DOI: https://doi.org/10.20952/revtee.v10i23.7441

TANCREDI, Regina Maria Simões Puccinelli. Políticas públicas de formação de professores: o Pibid em foco. Revista Exitus, v. 3, n. 1, jan./jun. 2013, p. 13-31. ISSN 2237-9460. Disponível em: 〈http://www.ufopa.edu.br/portaldeperiodicos/index.php/revistaexitus/article/view/246> Acessado em: 17 abr. 2020. 
TANCREDI, Regina Maria Simões Puccinelli; REALI, Aline Maria Medeiros Rodrigues. O que um mentor precisa saber? Ou: sobre a necessidade de um mentor construir uma visão multifocal. Revista Exitus, v. 1, n. 1, jan./jun. 2011, p. 35-46. ISSN 2237-9660. Disponível em: <http://www.ufopa.edu.br/portaldeperiodicos/index.php/revistaexitus/article/view/203 > Acesso em: 17 abr. 2020.

TEIXEIRA, Eliara Cristina Nogueira; NUNES, Claudio Pinto. Os sentidos atribuídos ao piso salarial nacional como política pública de valorização docente. Revista Tempos e Espaços em Educação, Aracaju, v. 12, n. 29, p. 195-212, 2019. Disponível em:

https://seer.ufs.br/index.php/revtee/article/view/10688. Acesso em: 22 abr. 2020.

ULJENS, M. Non-Affirmative curriculum theory in a cosmopolitan era?. Revista Tempos e Espaços em Educação, São Cristóvão, v. 9, n. 18, p. 121-132, 2016. Disponível em: <https://seer.ufs.br/index.php/revtee/article/view/4970>. Acesso em: 21 mai. 2020. DOI: https://doi.org/10.20952/revtee.v9i18.4970.

VALENTE, Geilsa Soraia Cavalcanti; VIANA, Ligia de Oliveira. O ensino de nível superior no brasil e as competências docentes: um olhar reflexivo sobre esta prática. Revista Práxis

Educacional, Vitória da Conquista, v. 6, n. 9, p. 209-226, out. 2010. ISSN 2178-2679. Disponível em: 〈http://periodicos2.uesb.br/index.php/praxis/article/view/641〉. Acesso em: 17 abr. 2020.

VERCEZE, Rosa Maria Aparecida Nechi; SILVINO, Eliziane França Moreira. O livro didático e suas implicações na prática do professor nas escolas públicas de Guajará-mirim. Revista Práxis Educacional, Vitória da Conquista, v. 4, n. 4, p. 83-102, out. 2010. ISSN 2178-2679. Disponível em: 〈http://periodicos2.uesb.br/index.php/praxis/article/view/562〉. Acesso em: 17 abr. 2020.

\section{SOBRE OS AUTORES:}

\section{Pedro Paulo Souza Rios}

Doutorado em Educação, Universidade Federal de Sergipe - UFS; Professor na Universidade do Estado da Bahia - UNEB, Campus VII - Brasil; Coordenador do Grupo de Pesquisa e Estudos em Educação, Gênero e Sexualidades do Sertão - GENESES-Sertão. E-mail: peudesouza@yahoo.com.br

(iD http://orcid.org/0000-0001-7981-9091

\section{André Ricardo Lucas Vieira}

Doutorando em Educação, Universidade Federal de Sergipe - UFS, Professor Instituto Federal do Sertão Pernambucano - Brasil, E-mail: sistlin@uol.com

(iD http://orcid.org/0000-0002-9279-5802

\section{Willian Lima}

Mestrando em Educação, Universidade Federal de Sergipe - UFS; Núcleo de Pesquisa em Comunicação e Tecnologia - NUCA/UFS; Bolsista CAPES. E-mail: willianjere@ hotmail.com

(iD http://orcid.org/0000-0002-9298-1226 